\title{
Effect of number of parents on some important biometric genetic parameters in rapeseed (Brassica napus L.)
}

\author{
Valiollah Rameeh \\ Crop and Horticultural Science Research Department, Mazandaran Agricultural and Natural \\ Resources Research and Education Center, AREEO, Postal code: 48175556, Sari, Iran \\ e:mail:vrameeh@gmail.com
}

\section{SUMMARY}

\begin{abstract}
Half $F_{2}$ diallel crosses of eight spring cultivars of rapeseed were used in partial circulant diallel analyses to estimate biometric genetic parameters for phenological traits, yield components and seed yield. The greatest variation in the GCA-to-SCA mean square ratio was related to days to flowering, and its lowest variation to days to maturity. A high coefficient of variation of the narrow-sense heritability estimate was obtained for days to maturity, followed by plant height and seed yield. For diallel analysis with a low number of parents, the differences of the heritability estimates of the traits were small; therefore, for precise estimation of heritability, a high number of diallel crosses will be preferred.
\end{abstract}

Key words: diallel crosses, narrow-sense heritability, seed yield.

\section{Introduction}

In breeding programs, it is necessary to use adequate methodologies to deal with phenotypic data in order to correctly understand the estimates of genetic parameters and hence to rank the genotypes correctly. Diallel crossing is a widely used method by which the performance of a group of parents can be evaluated on an individual basis and also in hybrid combinations; it can also be used for determining the gene action of quantitative traits (Singh et al. 2010). Many extensions to Griffing's model have been proposed to extract more precise effects from the diallel. These include decomposing specific combing ability (SCA) into dominance, heterosis, and epistasis components (Hayman 1957; Gardner and Eberhart 1966) and into reciprocal effects (Griffing 1956), 
and their further decomposition into maternal and paternal effects (Cockerham and Weir 1977; Zhu and Weir 1996). Conversely, interest in obtaining general combining ability (GCA) with a reduced number of crosses has motivated variants of the design such as the half-diallel (Griffing 1956) and the partial diallel (Kempthorne and Curnow 1961), among others (Lynch and Walsh 1998), which have themselves led to nominal innovation (Greenberg et al. 2010). Knowledge of genetic control of agronomic traits is very important for plant breeders to formulate a proper breeding strategy for the improvement of new oilseed brassica varieties. Singh and Chaudhry (2004) state that the heritability of a trait approaches its maximum in successive generations following hybridization. In addition, the presence of additive gene effects for a trait indicates that selection may be successful for the trait (Mather and Jinks 1982; Kearsey and Pooni 1996). Estimation of the genetic constitution of the parents for seed yield and its components can be important for indirect selection for high seed yield in rapeseed (Downey and Rimer 1993; Nassimi et al. 2006; Singh et al. 2010; Teklewold and Becker 2005; Yadav et al. 2005). Although combining ability studies in oilseed Brassica spp. are scanty, most such studies have emphasized the preponderance effect of GCA for yield and its components, indicating the importance of additive gene action (McGee and Brown 1995; Wos et al. 1999; Rameeh 2011). Khan et al. (2006) reported that variation for both GCA and SCA was responsible for dry matter yield and other quantitative traits in B. napus. Significant GCA and SCA effects were reported for pods per main raceme, pods per plant, pod length, number of seeds per pod, 1000-seed weight and seed yield in B. napus (Thakur and Sagwal 1997; Mahmud et al. 2009), but in another study (Singh et al. 1995) the importance of additive genetic effects for pods per plant and 1000-seed weight was emphasized. Singh and Yadav (1980) and Thakur and Sagwal (1997), in examining the genetic control of seed yield in rapeseed, found both additive and non-additive gene effects to be involved. Khan and Khan (2005) performed a complete diallel cross analysis in rapeseed and reported that number of pods per plant, 1000-seed weight and seed yield per plot had moderate narrow-sense heritability. A limiting factor for the use of diallel crosses is the large number of parents that have to be evaluated in some cases. An alternative is to evaluate only 
a sample of these parents in a so-called circulant diallel method (Alan et al. 2012). The circulant diallel suggested by Kempthorne and Curnow (1961) justifies special consideration because it permits the use of a reduced number of parents, although questionable estimates of GCA and SCA may result when the number of crosses per parent is too small. There have been only a few studies dealing with these issues (Murty and Anand 1966; Murty et al. 1967).

The objective of the present study was to estimate biological genetic parameters for phenological traits, plant height, seed yield and its components in eight rapeseed breeding lines using partial circulant diallel analysis.

\section{Materials and methods}

Eight rapeseed (Brassica napus L.) spring genotypes including L41, Zafar, L56, L31, L22, LF2, L420 and L401 (all of the genotypes were $\mathrm{F}_{7}$ generation with coefficient of inbreeding one $(\mathrm{F}=1)$ and were selected based on a pedigree method in a northern province of Iran) were crossed in a half diallel mating design during 2011-12. The hand cross-pollinated flowers on the inflorescences were isolated using paper to produce an $F_{1}$ generation. Twenty-eight $F_{1}$ crosses along with their parents (36 in total) were planted in a randomized complete block design with three replications at Bayekola Agriculture Research Station, located in Neka, Iran (13 $53^{\prime} \mathrm{E}$ longitude and $43^{\circ} 36^{\prime} \mathrm{N}$ latitude, $15 \mathrm{~m}$ above sea level) during autumn in 2012-13. In both years the genotypes were sown on October 10. The soil was classified as a deep loam soil (Typic Xerofluents, USDA classification), and contained an average of $280 \mathrm{~g}$ clay kg-1, $560 \mathrm{~g}$ silt kg $\mathrm{kg}^{-1}, 160 \mathrm{~g}$ sand $\mathrm{kg}^{-1}$ and $22.4 \mathrm{~g}$ organic matter $\mathrm{kg}^{-1}$, with a $\mathrm{pH}$ of 7.3. Soil samples were found to have $45 \mathrm{~kg} \mathrm{ha}^{-1}$ of mineral nitrogen $(\mathrm{N})$ in the upper $30 \mathrm{~cm}$ profile. The plots consisted of four rows $5 \mathrm{~m}$ long and $40 \mathrm{~cm}$ apart, and the distance between plants in each row was $5 \mathrm{~cm}$. The site had been planted with wheat in the previous year. Phosphorus $(\mathrm{P})$ and potassium $(\mathrm{K})$ were applied at $100 \mathrm{~kg} \mathrm{ha}^{-1}$ and $150 \mathrm{~kg}$ $\mathrm{ha}^{-1}$ using potassium sulfate $(48 \% \mathrm{~K} 2 \mathrm{O})$ and triple super phosphate $(48 \% \mathrm{P} 2 \mathrm{O} 5)$ respectively. Nitrogen was applied at $180 \mathrm{~kg} \mathrm{ha}^{-1}$, which included $391 \mathrm{~kg} \mathrm{ha}^{-1}$ urea $(46 \% \mathrm{~N})$. Management of the trial involved the broadcasting of a third of the 
nitrogen and the whole of the phosphorus and potassium fertilizers along with spraying of trifluralin (a,a,a-Trifluoro-2,6-dinitro-N,N-dipropyl-p-toluidine) herbicide at 2 lit/ha, followed by harrowing to incorporate the pre-emergent herbicide and fertilizers. Seeds were sown on the plots by hand with a $2 \mathrm{~cm}$ depth on October 29, 2012. A third of the nitrogen was applied at the time of sowing, a third at the beginning of stem elongation and the rest at the flowering period. The plots were hand weeded during the season. Maximum and minimum temperatures and precipitation were recorded at $35{ }^{\circ} \mathrm{C},-4{ }^{\circ} \mathrm{C}$ and $485 \mathrm{~mm}$ respectively. All plant protection measures were applied to ensure that the crop was free of insects. Seed yield (adjusted to $\mathrm{kg} \mathrm{ha}^{-1}$ ) was recorded based on the two middle rows of each plot, and plant height and yield components were measured based on 10 randomly selected plants in each plot.

Combining ability was analyzed using partial circulant diallel analysis with different numbers of parents $(\mathrm{N}=4,5,6,7,8)$ and their $\mathrm{F}_{1}$ generations using Griffing's method 2 with mixed-B model (Griffing 1956). The linear model of observations in this method is of the form:

$$
X_{i j}=\mu+g_{i}+q_{j}+s_{i j}+\frac{1}{b} \sum_{k=1}^{b} e_{i j k}
$$

$(i=j=1 \ldots ; k=1, \ldots, b)$, where $u$ - the population mean; $g_{i}$ - the general combining ability effect of the $i$ th parent; $q_{j}-$ the general combining ability effect of the $j$ th parent; $s_{i j}$ - the specific combining ability effect of the cross between the $i$ th and $j$ th parents, such that $s_{i j}=s_{j i}$; and $e_{i j k}-$ the environmental effect associated with the $i j k$ th observation.

$$
\begin{aligned}
& \mathrm{V}_{(\mathrm{GCA})}=\frac{\mathrm{MS}_{(\mathrm{GCA})}-\mathrm{MS}_{\mathrm{E}}}{\mathrm{n}+2}=\frac{1+\mathrm{F}}{4} \mathrm{~V}_{\mathrm{A}} \\
& \mathrm{V}_{(\mathrm{SCA})}=\mathrm{MS}_{(\mathrm{SCA})}-\mathrm{MS}_{\mathrm{E}} \\
& \mathrm{V}_{(\mathrm{SCA})}=\mathrm{COV}_{\mathrm{F} . \mathrm{S}}-2 \mathrm{COV}_{\mathrm{H} . \mathrm{S}}=\frac{1+\mathrm{F}}{2}\left(\mathrm{~V}_{\mathrm{A}}+\mathrm{V}_{\mathrm{D}}\right)-2 \frac{1+\mathrm{F}}{4} \mathrm{~V}_{\mathrm{A}}=\frac{1+\mathrm{F}}{2} \mathrm{~V}_{\mathrm{D}}
\end{aligned}
$$




$$
\text { If } \mathrm{F}=1: \mathrm{V}_{(\mathrm{GCA})}=\frac{1}{2} \mathrm{~V}_{\mathrm{A}} \text { and } \mathrm{V}_{(\mathrm{SCA})}=\mathrm{V}_{\mathrm{D}}
$$

where $\mathrm{V}_{(\mathrm{GCA})}=$ variance of general combining ability, $\mathrm{MS}_{(\mathrm{GCA})}=$ mean square of general combining ability, $\mathrm{MS}_{\mathrm{E}}=$ mean square error, $\mathrm{n}=$ number of parents, $\mathrm{F}=$ coefficient of inbreeding, $\mathrm{V}_{\mathrm{A}}=$ additive variance, $\mathrm{V}_{(\mathrm{SCA})}=$ variance of specific combining ability, $\mathrm{MS}_{(\mathrm{SCA})}=$ mean square of specific combining ability, $\mathrm{COV}_{\mathrm{F} . \mathrm{S}}=$ covariance between full-sibs, $\mathrm{COV}_{\mathrm{H} . \mathrm{S}}=$ covariance between half-sibs, and $\mathrm{V}_{\mathrm{D}}=$ dominance variance. All analyses were performed using MS-Excel and SAS software (Zhang and Kang 1997).

\section{Results and discussion}

The results of diallel analysis using Griffing's method 2 with mixed-B model for traits including days to flowering, days to maturity, plant height, first branching height, number of branches and seed yield for parent numbers 4, 5, 6, 7 and 8 are presented in Tables 1, 2, 3, 4 and 5. Significant mean squares of GCA for the parents and also SCA for their crosses were obtained for the traits in most of the analyses, indicating the importance of additive and non-additive genetic effects for these traits. Similarly, significant GCA and SCA effects have been reported for some important agronomic traits in Brassica napus L. (Downey and Rimer 1993; Rameeh 2010) and other brassica species (Nassimi et al. 2006). Due to the use of different numbers of parents in partial circulant diallel analyses, the SCA mean square of the traits was more affected than the GCA mean squares. The SCA mean square was not significant for first branching height and number of branches in the diallel analysis with number of parents $\mathrm{N}=7$, similarly for plant height with $\mathrm{N}=6$, for pods on main raceme with $\mathrm{N}=5$, and for days to flowering, first branching height and pods on main raceme with $\mathrm{N}=4$. 
Table 1. Diallel analysis of phenological traits, plant height, yield components and seed yield of eight parents $(\mathrm{N}=8)$ of rapeseed (Brassica napus L.) based on Griffing's method 2

\begin{tabular}{lllllllll}
\hline S.O.V. & df & \multicolumn{7}{c}{ M.S. } \\
\cline { 3 - 8 } & & $\begin{array}{l}\text { Days to } \\
\text { flowering }\end{array}$ & $\begin{array}{l}\text { Days to } \\
\text { maturity }\end{array}$ & $\begin{array}{l}\text { Plant } \\
\text { height }\end{array}$ & $\begin{array}{l}\text { First } \\
\text { branching } \\
\text { height }\end{array}$ & $\begin{array}{l}\text { Number } \\
\text { of } \\
\text { branches }\end{array}$ & $\begin{array}{l}\text { Pods on } \\
\text { main } \\
\text { raceme }\end{array}$ & Seed yield \\
\hline Repli- & & & & & & & \\
cation & 2 & 16.1 & 4.7 & $275.3^{*}$ & $906.9^{* *}$ & 1.60 & 79.9 & $1571000^{* *}$ \\
Crosses & 35 & $913.3^{* *}$ & $424.8^{* *}$ & $593.7^{* *}$ & $610.0^{* *}$ & $1.91^{* *}$ & $359.4^{* *}$ & $387481^{* *}$ \\
GCA & 7 & $3979.2^{* *}$ & $798.8^{* *}$ & $1526.9^{* *}$ & $1469.8^{* *}$ & $4.77^{* *}$ & $1181.7^{* *}$ & $975122^{* *}$ \\
SCA & 28 & $146.8^{* *}$ & $331.3^{* *}$ & $360.4^{* *}$ & $395.1^{* *}$ & $1.20^{*}$ & $153.9^{* *}$ & $240570^{* *}$ \\
Error & 70 & 7.6 & 2.7 & 151.1 & 178.0 & 0.72 & 27.5 & 64580 \\
\hline
\end{tabular}

Table 2. Diallel analysis of phenological traits, plant height, yield components and seed yield of seven parents ( $\mathrm{N}=7$ ) of rapeseed (Brassica napus L.) based on Griffing's method 2

\begin{tabular}{|c|c|c|c|c|c|c|c|c|}
\hline \multirow[t]{2}{*}{ S.O.V. } & \multirow[t]{2}{*}{ df } & \multicolumn{7}{|c|}{ M.S } \\
\hline & & $\begin{array}{l}\text { Days to } \\
\text { flowering }\end{array}$ & $\begin{array}{l}\text { Days to } \\
\text { maturity }\end{array}$ & $\begin{array}{l}\text { Plant } \\
\text { height }\end{array}$ & $\begin{array}{l}\text { First } \\
\text { branching } \\
\text { height }\end{array}$ & $\begin{array}{l}\text { Number } \\
\text { of } \\
\text { branches }\end{array}$ & $\begin{array}{l}\text { Pods on } \\
\text { main } \\
\text { raceme }\end{array}$ & Seed yield \\
\hline Replication & 2 & $25.2^{*}$ & 4.4 & 260.8 & 307.7 & $1.58 *$ & 53.1 & $1392000^{* * *}$ \\
\hline Crosses & 27 & $600.1 * *$ & $271.4 * *$ & $426.6 * *$ & $488.9 * *$ & $1.86 * *$ & $290.4 * *$ & $367177 * *$ \\
\hline GCA & 6 & $2489.8 * *$ & $431.7 * *$ & $1059.4 * *$ & $1177.5^{* *}$ & $5.83 * *$ & $894.0 * *$ & $886969 * *$ \\
\hline SCA & 21 & $60.2 * *$ & $225.7 * *$ & $245.8 *$ & 292.2 & 0.73 & $117.9 * *$ & $218665^{* * *}$ \\
\hline Error & 54 & 7.4 & 1.6 & 125.6 & 167.2 & 0.49 & 28.7 & 65840 \\
\hline
\end{tabular}

Table 3. Diallel analysis of phenological traits, plant height, yield components and seed yield of six parents $(\mathrm{N}=6)$ of rapeseed (Brassica napus L.) based on Griffing's method 2

\begin{tabular}{lllllllll}
\hline S.O.V. & df & \multicolumn{9}{c}{ M.S } \\
\cline { 3 - 9 } & & $\begin{array}{l}\text { Days to } \\
\text { flowering }\end{array}$ & $\begin{array}{l}\text { Days to } \\
\text { maturity }\end{array}$ & $\begin{array}{l}\text { Plant } \\
\text { height }\end{array}$ & $\begin{array}{l}\text { First } \\
\text { branching } \\
\text { height }\end{array}$ & $\begin{array}{l}\text { Number } \\
\text { of } \\
\text { branches }\end{array}$ & $\begin{array}{l}\text { Pods on } \\
\text { main } \\
\text { raceme }\end{array}$ \\
\hline Replication & 2 & $23.3^{*}$ & 1.2 & 163.3 & 326.5 & 0.40 & 29.3 & $920920^{* *}$ \\
Crosses & 20 & $50.6^{* *}$ & $55.7^{* *}$ & $360.7 * *$ & $502.9 * *$ & $2.09^{* *}$ & $266.5 * *$ & $397724^{* *}$ \\
GCA & 5 & $136.1^{* *}$ & $139.7^{* *}$ & $1053.1^{* *}$ & $1218.6^{* *}$ & $5.88^{* *}$ & $703.4^{* *}$ & $1079000^{* *}$ \\
SCA & 15 & $22.0^{* *}$ & $27.8^{* *}$ & 130.0 & $264.4^{*}$ & $0.82^{*}$ & $120.8^{* *}$ & $170686^{* *}$ \\
Error & 40 & 5.9 & 1.7 & 109.6 & 136.0 & 0.37 & 28.0 & 54272 \\
\hline
\end{tabular}

$*, * *$ Significant at $\mathrm{p}<0.05$ and 0.01 , respectively, GCA: general combining ability, SCA: specific combing ability 
Table 4. Diallel analysis of phenological traits, plant height, yield components and seed yield of five parents ( $\mathrm{N}=5$ ) of rapeseed (Brassica napus L.) based on Griffing's method 2

\begin{tabular}{|c|c|c|c|c|c|c|c|c|}
\hline \multirow[t]{2}{*}{ S.O.V. } & \multirow[t]{2}{*}{ df } & \multicolumn{7}{|c|}{ M.S } \\
\hline & & $\begin{array}{l}\text { Days to } \\
\text { flowering }\end{array}$ & $\begin{array}{l}\text { Days to } \\
\text { maturity }\end{array}$ & $\begin{array}{l}\text { Plant } \\
\text { height }\end{array}$ & $\begin{array}{l}\text { First } \\
\text { branching } \\
\text { height }\end{array}$ & $\begin{array}{l}\text { Number } \\
\text { of } \\
\text { branches }\end{array}$ & $\begin{array}{l}\text { Pods on } \\
\text { main } \\
\text { raceme }\end{array}$ & Seed yield \\
\hline Replication & 2 & 17.2 & 1.4 & 24.0 & 131.0 & 0.05 & 25.0 & $487678 * *$ \\
\hline Crosses & 14 & $37.7 * *$ & $12.9 * *$ & $396.7 * *$ & $467.1 * *$ & $2.26^{* *}$ & $89.7 * *$ & $446317 * *$ \\
\hline GCA & 4 & $110.9 * *$ & $23.9^{* * *}$ & $1179.0^{* *}$ & $1183.7 * *$ & $5.67 * *$ & $243.3 * *$ & $1282000 * *$ \\
\hline SCA & 10 & $8.4^{*}$ & $8.5^{* *}$ & $83.8 *$ & $180.4^{*}$ & $0.90 *$ & 28.3 & $112185^{* *}$ \\
\hline Error & 28 & 5.1 & 1.4 & 41.7 & 89.9 & 0.35 & 21.6 & 31374 \\
\hline
\end{tabular}

Table 5. Diallel analysis of phenological traits, plant height, yield components and seed yield of four parents ( $\mathrm{N}=4$ ) of rapeseed (Brassica napus L.) based on Griffing's method 2

\begin{tabular}{|c|c|c|c|c|c|c|c|c|}
\hline \multirow[t]{2}{*}{ S.O.V. } & \multirow[t]{2}{*}{$\mathrm{df}$} & \multicolumn{7}{|c|}{ M.S } \\
\hline & & $\begin{array}{l}\text { Days to } \\
\text { flowering }\end{array}$ & $\begin{array}{l}\text { Days to } \\
\text { maturity }\end{array}$ & $\begin{array}{l}\text { Plant } \\
\text { height }\end{array}$ & $\begin{array}{l}\text { First } \\
\text { branching } \\
\text { height }\end{array}$ & $\begin{array}{l}\text { Number } \\
\text { of } \\
\text { branches }\end{array}$ & $\begin{array}{l}\text { Pods on } \\
\text { main } \\
\text { raceme }\end{array}$ & $\begin{array}{l}\text { Seed } \\
\text { yield }\end{array}$ \\
\hline Replication & 2 & 19.7 & 0.83 & 61.9 & 152.9 & 0.08 & 21.3 & $264710 * *$ \\
\hline Crosses & 9 & $45.3 * *$ & $9.89 * *$ & $541.5 * *$ & $700.5 * *$ & $2.52 * *$ & $89.8 * *$ & $351221 * *$ \\
\hline GCA & 3 & $121.3 * *$ & $15.13^{* *}$ & $1379.1 * *$ & $1641.6^{* *}$ & $5.90 * *$ & $221.4 * *$ & $856083^{* *}$ \\
\hline SCA & 6 & 7.4 & $7.26^{* *}$ & $122.7 *$ & 230.0 & $0.84 * *$ & 24.0 & $98791 * *$ \\
\hline Error & 18 & 7.0 & 1.24 & 54.5 & 121.2 & 0.11 & 23.4 & 27475 \\
\hline
\end{tabular}

\section{Biometric genetic parameters}

The GCA-to-SCA mean square ratio $\left(\mathrm{MS}_{(\mathrm{GCA})} / \mathrm{MS}_{(\mathrm{SCA})}\right)$, which indicates the prime importance of additive genetic effects, ranged from 20.85 to 2.85 , for days to flowering and days to maturity respectively (Table 6). The greatest variation of this genetic parameter was related to days to flowering, and its lowest variation to days to maturity. Due to the reduction of the number of parents in diallel analysis, except for days to flowering and days to maturity, for the other traits the mean square ratio $\left(\mathrm{MS}_{(\mathrm{GCA})} / \mathrm{MS}_{(\mathrm{SCA})}\right)$ increased. The greatest amounts of variation of this index were related to days to flowering, days to maturity, plant height and seed yield.

Additive variance $\left(\mathrm{V}_{\mathrm{A}}\right)$ as affected by the different numbers of parents in the diallel analysis, and its trend, varied between the traits. A high value of the 
coefficient of variation $(\mathrm{CV})$ of additive variance $\left(\mathrm{V}_{\mathrm{A}}\right)$ for the use of different numbers of parents was recorded for days to flowering and days to maturity (Table 6). Singh and Chaudhry (2004) state that the heritability of a trait approaches its maximum in successive generations following hybridization. In addition, the presence of additive gene effects for a trait indicates that selection may be successful for the trait (Mather and Jinks 1982; Kearsey and Pooni 1996).

For all traits, as the number of parents in the diallel analysis was reduced, dominance variance $\left(V_{D}\right)$ greatly decreased. Large variation of $V_{D}$ was found for days to flowering, days to maturity, plant height and pods on main raceme. Dominance variance ranged from 0.49 to 119,471 for number of branches and seed yield respectively. The greatest reduction of $V_{D}$ for a low number of parents $(\mathrm{N}=4)$ in diallel analysis was obtained for days to flowering.

Heritability, a measure of the phenotypic variance attributable to genetic causes, has a predictive function in crop breeding. The higher the heritability estimates, the simpler are the selection procedures (Mather and Jinks 1982). High narrow-sense heritability was estimated for days to flowering and pods on main axis. Khan and Khan (2005) performed a complete diallel cross analysis in rapeseed and reported that number of pods per plant, 1000-seed weight and seed yield per plot had moderate narrow-sense heritability. The greatest fluctuation of narrow-sense heritability estimates obtained from partial circulant diallel analyses was detected for days to maturity, followed by plant height and seed yield (Table 6). For diallel analysis with a low number of parents $(\mathrm{N}=5,6)$ the differences of the heritability estimates of the traits were low; therefore, for precise estimation of heritability, a high number of diallel crosses will be preferred. In a simulation study, Pederson (1972) concluded that circulant diallels yield good estimates of heritability. Results reported by other authors (Pederson 1972; Ferreira et al. 2004) have shown that when a small number of crosses is used, the heritability values are less reliable because the estimates tend to be farther away from the parametric values. Results reported in the literature concerning the number of crosses per parent (s) in circulant diallels are quite different. 
The degree of dominance ranged from 0.27 to 1.11 , for days to flowering and days to maturity respectively. High variation in the degree of dominance due to the use of different numbers of parents was determined for days to flowering, plant height and pods on main raceme; therefore, a high number of parents should be used in diallel crosses for greater precision as regards the degree of dominance of these traits.

Table 6. Biometric genetic parameters of phenological traits, plant height, yield components and seed yield of rapeseed (Brassica napus L.) based on Griffing's method 2

\begin{tabular}{|c|c|c|c|c|c|c|c|c|}
\hline $\begin{array}{l}\text { Biometric } \\
\text { genetic } \\
\text { parameters }\end{array}$ & $\begin{array}{l}\text { Number } \\
\text { of } \\
\text { parents }\end{array}$ & $\begin{array}{l}\text { Days to } \\
\text { flowering }\end{array}$ & $\begin{array}{l}\text { Days to } \\
\text { maturity }\end{array}$ & $\begin{array}{l}\text { Plant } \\
\text { height }\end{array}$ & $\begin{array}{l}\text { First } \\
\text { branching } \\
\text { height }\end{array}$ & $\begin{array}{l}\text { Number } \\
\text { of } \\
\text { branches }\end{array}$ & $\begin{array}{l}\text { Pods } \\
\text { on } \\
\text { main } \\
\text { raceme }\end{array}$ & $\begin{array}{l}\text { Seed } \\
\text { yield }\end{array}$ \\
\hline \multirow{7}{*}{$\begin{array}{l}\mathrm{MS}(\mathrm{GCA}) / \\
\mathrm{MS}(\mathrm{SCA})\end{array}$} & $\mathrm{N}=8$ & 27.11 & 2.41 & 4.24 & 3.72 & 3.98 & 7.68 & 4.05 \\
\hline & $\mathrm{N}=7$ & 41.36 & 1.91 & 4.31 & 4.03 & 7.99 & 7.58 & 4.06 \\
\hline & $\mathrm{N}=6$ & 6.19 & 5.03 & 8.10 & 4.61 & 7.17 & 5.82 & 6.32 \\
\hline & $\mathrm{N}=5$ & 13.20 & 2.81 & 14.07 & 6.56 & 6.30 & 8.60 & 11.43 \\
\hline & $\mathrm{N}=4$ & 16.39 & 2.08 & 11.24 & 7.14 & 7.02 & 9.23 & 8.67 \\
\hline & mean & 20.85 & 2.85 & 8.39 & 5.21 & 6.49 & 7.78 & 6.91 \\
\hline & CV $(\%)$ & 65.81 & 44.50 & 51.37 & 29.60 & 23.52 & 16.59 & 45.89 \\
\hline \multirow{7}{*}{$V_{(A)}$} & $\mathrm{N}=8$ & 766.48 & 93.50 & 233.30 & 214.94 & 0.71 & 205.56 & 146910 \\
\hline & $\mathrm{N}=7$ & 539.91 & 45.78 & 180.80 & 196.73 & 1.13 & 172.47 & 148512 \\
\hline & $\mathrm{N}=6$ & 28.53 & 27.98 & 230.78 & 238.55 & 1.27 & 145.65 & 227079 \\
\hline & $\mathrm{N}=5$ & 29.29 & 4.40 & 312.91 & 286.66 & 1.36 & 61.43 & 334233 \\
\hline & $\mathrm{N}=4$ & 37.97 & 2.62 & 418.80 & 470.53 & 1.69 & 65.80 & 252431 \\
\hline & mean & 280.44 & 34.86 & 275.32 & 281.48 & 1.23 & 130.18 & 221833 \\
\hline & CV $(\%)$ & 124.66 & 107.08 & 33.82 & 39.41 & 29.00 & 49.46 & 35.34 \\
\hline \multirow{7}{*}{$V_{(D)}$} & $\mathrm{N}=8$ & 139.20 & 328.60 & 209.30 & 217.10 & 0.48 & 126.40 & 175990 \\
\hline & $\mathrm{N}=7$ & 52.80 & 224.10 & 120.20 & 125.00 & 0.24 & 89.20 & 152825 \\
\hline & $\mathrm{N}=6$ & 16.10 & 26.10 & 20.40 & 128.40 & 0.45 & 92.80 & 116414 \\
\hline & $\mathrm{N}=5$ & 3.30 & 7.10 & 42.10 & 90.50 & 0.55 & 6.70 & 80811 \\
\hline & $\mathrm{N}=4$ & 0.40 & 6.02 & 68.20 & 108.80 & 0.73 & 0.60 & 71316 \\
\hline & mean & 42.36 & 118.38 & 92.04 & 133.96 & 0.49 & 63.14 & 119471 \\
\hline & CV (\%) & 136.96 & 125.92 & 81.92 & 36.47 & 36.13 & 89.09 & 37.74 \\
\hline \multirow{7}{*}{$h^{2} \mathrm{~N}$} & $\mathrm{~N}=8$ & 0.84 & 0.22 & 0.39 & 0.35 & 0.37 & 0.57 & 0.38 \\
\hline & $\mathrm{N}=7$ & 0.90 & 0.17 & 0.42 & 0.40 & 0.61 & 0.59 & 0.40 \\
\hline & $\mathrm{N}=6$ & 0.56 & 0.50 & 0.64 & 0.47 & 0.61 & 0.55 & 0.57 \\
\hline & $\mathrm{N}=5$ & 0.78 & 0.34 & 0.79 & 0.61 & 0.60 & 0.68 & 0.75 \\
\hline & $\mathrm{N}=4$ & 0.84 & 0.27 & 0.77 & 0.67 & 0.67 & 0.73 & 0.72 \\
\hline & mean & 0.78 & 0.30 & 0.60 & 0.50 & 0.57 & 0.62 & 0.56 \\
\hline & $\mathrm{CV}(\%)$ & 16.86 & 42.75 & 31.42 & 27.28 & 20.33 & 12.39 & 30.67 \\
\hline \multirow{7}{*}{$\mathrm{d} / \mathrm{a}$} & $\mathrm{N}=8$ & 0.30 & 1.33 & 0.67 & 0.71 & 0.58 & 0.55 & 0.77 \\
\hline & $\mathrm{N}=7$ & 0.22 & 1.56 & 0.58 & 0.56 & 0.33 & 0.51 & 0.72 \\
\hline & $\mathrm{N}=6$ & 0.53 & 0.68 & 0.21 & 0.52 & 0.42 & 0.56 & 0.51 \\
\hline & $\mathrm{N}=5$ & 0.24 & 0.90 & 0.26 & 0.40 & 0.45 & 0.23 & 0.35 \\
\hline & $\mathrm{N}=4$ & 0.07 & 1.07 & 0.29 & 0.34 & 0.47 & 0.07 & 0.38 \\
\hline & mean & 0.27 & 1.11 & 0.40 & 0.51 & 0.45 & 0.38 & 0.55 \\
\hline & $\mathrm{CV}(\%)$ & 61.49 & 31.31 & 51.74 & 28.56 & 20.06 & 57.75 & 35.20 \\
\hline
\end{tabular}




\section{Conclusions}

All biometric genetic parameters were affected by a reduction in the number of parents used in diallel analysis. The greatest variation in $\mathrm{MS}_{(\mathrm{GCA})} / \mathrm{MS}_{(\mathrm{SCA})}$ was related to days to flowering, and the lowest variation to days to maturity. Due to reduction of the number of parents in diallel analysis, except for days to flowering and days to maturity, for the other traits $\mathrm{MS}_{(\mathrm{GCA})} / \mathrm{MS}_{(\mathrm{SCA})}$ increased. The greatest fluctuation of narrow-sense heritability estimates obtained from partial circulant diallel analyses was detected for days to maturity, followed by plant height and seed yield. With a low number of parents in diallel analysis the differences in the heritability estimates of the traits were low; therefore, for precise estimation of heritability, a high number of diallel crosses will be preferred.

\section{Acknowledgements}

The author wishes to thank the Agricultural and Natural Resources Research and Education Center of Mazandaran and the Seed and Plant Improvement Institute (SPII) for providing genetic materials and facilities for conducting the experiment.

\section{REFERENCES}

Alan B.L., Svenson K.L., Churchill G.A., Valdar W. (2012): A General Bayesian Approach to Analyzing Diallel Crosses of Inbred Strains. Genetics 190: 413-435.

Cockerham C.C. (1963): Estimation of genetic variances, pp. 53-94. In W.D. Hanson and H.F. Robinson (ed.), Statistical Genetics and Plant Breeding. National Research Council Publication 982, National Academy of Science, Washington, D.C.

Cockerham C., Weir B. (1977): Quadratic analyses of reciprocal crosses. Biometrics 33(1): 187-203.

Downey, R.K., Rimer S.R. (1993): Agronomic improvement in oilseed Brassicas. Advances in Agronomy 50: 1-150.

Ferreira F.M., Junior J.I.R., Patto Pacheco C.A., Osorio Silva S.H., Cruz C.D. (2004): Efficiency of circulant diallels as compared to complete diallels for the estimation of combining ability. Crop Breeding and Applied Biotechnology 4: 145-151.

Gardner C., Eberhart S. (1966): Analysis and interpretation of the variety cross diallel and related populations. Biometrics 22(3): 439-452. 
Greenberg A.J., Hackett S.R., Harshman L.G., Clark A.G. (2010): A hierarchical Bayesian model for a novel sparse partial diallel crossing design. Genetics 185(1): 361-373.

Griffing B. (1956): Concept of general and specific combining ability in relation to diallel crossing systems. Australian Journal of Biology Science 9: 463-493.

Hayman B.I. (1957): Interaction, heterosis and diallel crosses. Genetics 42: 336-355.

Jinks J.L. (1954): Analysis of continuous variation in diallel crosses of Nicotiana rustica. Genetics 39: 767-88.

Kearsey M.J., Pooni H.S. (1996): The Genetical Analysis of Quantitative Traits. Chapman and Hall, London.

Kempthorne O., Curnow R.N. (1961): The partial diallel crosses. Biometrics 17: 229-250.

Khan F.A., Khan R.S.A. (2005): Inheritance pattern of quantitative characters in Brassica napus. International Journal of Agriculture and Biology 7(3): 420-423.

Khan M.N., Shah S.A., Wani S.A., Zaffar G. (2006): Combining ability and gene action in gobhi sarson (Brassica napus L.). Advances in Plant Science 19(1): 285-293.

Lynch M., Walsh B. (1998): Genetics and Analysis of Quantitative Traits. Sinauer Associates, Sunderland, MA.

Mahmud F., Rasul M.G., Mian M.A.K., Rahim M.A. (2009): Combining ability and gene action for seed yield and yield components in Brassica napus L. International Journal of Agriculture Environment and Biotechnology 2(3): 235-242.

Mather K., Jinks J.L. (1982): Biometrical Genetics, 3rd Ed. Chapman and Hall, London.

McGee, K.P., Brown J. (1995): Investigation of $F_{1}$ hybrids performance in fall- and spring-planted canola. P. 116-118. In Proc. (th $^{\text {th }}$ In. Rapeseed Confr., 4-10 July 1995. Cambridge, U.K.

Murty B.R., Anand I.J. (1966): Combining ability and diversity in some varieties of Linus uritatissemum. Indian Journal of Genetics Plant Breeding 26: 21-36.

Nassimi A.W., Ali R.S., Hassan G., Ali N. (2006): Combining ability analysis for maturity and other traits in rapeseed (Brassica napus). Journal of Agronomy 5(3): 523-526.

Pederson D.G. (1972): A comparison of four experimental designs for the estimation of heritability. Theoretical and Applied Genetics 42: 371-377.

Rameeh V. (2011): Combining ability analysis of rapeseed genotypes under restricted nitrogen application. J. of Oilseed Brassica, 2(1): 7-12.

Singh, D., Malik V., Singh H. (1995): Gene action of seed yield and other desirable characters in oilseed rape (Brassica napus). Annals of Biology Ludhiana 11(1-2): 94-97.

Singh M., Singh L., Srivastava S.B.L. (2010): Combining ability analysis in Indian mustard (Brassica juncea). Journal of Oilseed Brassica, 1(1): 23-27.

Singh, R.K., Chaudhry B.D. (2004): Biometrical Methods in Quantitative Genetic Analysis. Kalyani Publishers, New Delhi, India.

Teklewold A., Becker H.C. (2005): Heterosis and combining ability in a diallel cross of Ethiopian Mustard inbred lines. Crop Sci. 45: 2629-2635.

Thakur H.L., Sagwal J.C. (1997): Heterosis and combining ability in oilseed rape (Brassica napus). Indian Journal of Genetics and Plant Breeding 57: 163-167. 
Wos H., Bartkowiak-Broda I., Budzianowski G., Krzymanski J. (1999): Breeding of winter and spring oilseed rape hybrids at Malyszyn. Paper 544. In Proc. 10th Int. Rapeseed Confr. [CD-ROM]. 26-29 Sep. 1999, Canberra, Australia.

Yadav Y.P., Prakash R., Singh R., Singh R.K., Yadav J.S. (2005): Genetics of yield and its component characters in Indian mustard (Brassica juncea (L.) Czern and Coss.) under rainfed conditions. Journal of Oilseed Research 22: 255-258.

Zhang Z., Kang S.K. (1997): A SAS Program for Griffing's Diallel Analyses. Agronomy Journal 89: 176-182.

Zhu J., Weir B. (1996): Mixed model approaches for diallel analysis based on a biomodel. Genetics Research 68(3): 233-240. 